\title{
A imersão social da economia em mercados alimentares brasileiros: uma abordagem institucionalista
}

\author{
Embeddedness in the brazilian's food markets: an institutionalist \\ approach
}

Abel Cassol ${ }^{1}$ (i), Sergio Schneider ${ }^{2}$ (1)

${ }^{1}$ Grupo de Estudos e Pesquisas em Agricultura, Alimentação e Desenvolvimento (GEPAD), Universidade Federal do Rio Grande do Sul (UFRGS), Porto Alegre (RS), Brasil. E-mail: abelcassol@hotmail.com

2Programas de Pós-graduação em Sociologia e Desenvolvimento Rural, Departamento de Sociologia, Universidade Federal do Rio Grande do Sul (UFRGS), Porto Alegre (RS), Brasil. E-mail: schneide@ufrgs.br

Como citar: Cassol, A., \& Schneider, S. (2022). A imersão social da economia em mercados alimentares brasileiros: uma abordagem institucionalista. Revista de Economia e Sociologia Rural, 60(2), e233766. https://doi.org/10.1590/18069479.2021 .233766

\begin{abstract}
Resumo: $O$ artigo tem como objetivo analisar a imersão social da economia em distintos mercados agroalimentares brasileiros a partir de uma perspectiva institucionalista. Embasado em um conjunto de autores, referências bibliográficas e entrevistas, visa complementar o debate sobre mercados na sociologia rural e econômica que tem privilegiado nas suas análises as abordagens de rede e de campo. O argumento defendido é o de que os atores sociais, antes de estabelecerem redes de relações e transações econômicas ou posicionarem-se no interior do campo (mercado) econômico, já compartilham um conjunto de valores culturais comuns (instituições) que são os responsáveis por construir os mercados locais nos quais interagem. A partir de pesquisa empírica demonstra-se como o processo de imersão social da economia em três mercados alimentares brasileiros - A Feira Central de Campina Grande/PB, a Feira de Caruaru/PE e a Feira do Pequeno Produtor de Passo Fundo/RS - é construído e reproduzido por meio de quatro instituições sociais principais: a barganha, a variedade de produtos ofertados, o preço e a qualidade atribuída aos alimentos. Por sua vez, são essas instituições as responsáveis por orientar as práticas de comercialização e consumo dos atores nos mercados pesquisados.
\end{abstract}

Palavras-chave: mercados agroalimentares, instituições sociais, sociologia econômica, consumo alimentar

Abstract: The present paper aims to analyse the embeddedness of the economy in different Brazilian agrifood markets from an institutionalist approach. Based on a set of authors, bibliographic references, and interviews, it proposes to complement the debate on markets in rural and economic sociology that preferential uses network and field approaches in its analyses. The argument defended is that social actors, before establishing economic networks and transactions or positioning themselves within the economic field (market), already share a set of common cultural values (institutions) that are responsible for building the local markets in which they interact. From empirical research, it is demonstrated how the process of embeddedness of the economy in three Brazilian food markets - the Central Fair of Campina Grande/PB, the Fair of Caruaru/PE, and the Small Producer Fair of Passo Fundo/RS - are built and reproduced through four main social institutions: bargain, the variety of products offered, the price and the quality attributed to the food. In turn, these institutions are responsible for guiding the marketing and consumption practices of the actors in the researched markets.

Keywords: agrifood markets, social institutions, economic sociology, food consumption.

\section{Introdução}

A emergência da sociologia econômica nas ciências sociais gerou uma renovação significativa na sociologia e na economia a partir da década de 1970. Um dos temas centrais nessa aproximação foram os estudos sociais sobre a dinâmica dos mercados. Na economia, os estudos de George Akerlof, Douglass North, Oliver Williamson e Elinor Ostrom abriram entradas importantes nesse 
campo. Na sociologia, os trabalhos de Harrison White, Mark Grannovetter, Richard Swedberg, Pierre Bourdieu, Neil Fligstein e Jens Beckert foram igualmente pioneiros.

Em maior ou menor medida, esses autores também colocaram no centro de suas análises a importância e a centralidade das instituições. Os economistas se esforçaram em mostrar que as instituições poderiam oferecer soluções inovadoras para o problema dos custos de transação crescentes das economias complexas, abordando questões como confiança, incerteza e competição, que renderam a muitos dos citados a láurea de Nobel da Economia. Os sociólogos, por seu turno, mostraram esmero e criatividade para retomar as questões culturais e políticas sobre representações coletivas e de coerção social, que eram os conceitos originais que definiam as instituições.

Na verdade, mercados e instituições passaram a ser tratados pela noção passe- partout de construção social. Do que resulta que hoje em dia é largamente aceito entre economistas e sociólogos que tanto mercados como instituições são construções sociais, ou socialmente construídos. A economia, nesse sentido, é influenciada pelas dimensões culturais, sociais, políticas, cognitivas que orientam as ações dos atores. Ela está, portanto, imersa no social.

Nos estudos sobre agricultura e produção alimentar, especialmente os situados no campo da sociologia rural, a discussão sobre mercados e instituições é mais recente. Se tomarmos o caso do Brasil, é possível afirmar que somente a partir da década de 1990 tanto economistas, como Décio Zylbersztajn e Mário Batalha, como sociólogos como Ricardo Abramovay e John Wilkinson - apenas para citar alguns - passaram a discutir e pesquisar os processos de construção social de instituições e mercados. Essa agenda, portanto, está aberta e precisa ser aprofundada.

Nos anos recentes, denota-se uma sinergia no campo dos estudos agroalimentares sobre mercados e instituições (Azevedo, 2016). Mas aqui economia e sociologia parecem que se dividem. Pelo lado da economia, mercados e instituições têm sido analisados dentro do escopo das abordagens convencionais, que discutem os processos de globalização controlados por grandes corporações e países hegemônicos (China e EUA). Por outro, a sociologia tem destacado cada vez mais a necessidade de se reconhecer processos sociais e locais assentados em "economias compartilhadas" ou "socialmente imersas", que atribuem novos significados e interpretações à economia contemporânea (Polanyi, 1980; Gaiger et al., 2019; Wong, 2020).

Essa economia localizada, com "cara", abre novos rumos à análise dos fenômenos econômicos. Cada vez mais as pessoas buscam reconhecimento por meio do consumo, preocupando-se com a origem daquilo que compram, com quais atores interagem ou como as mercadorias acessadas são fabricadas. Esse processo traz à tona o tema da confiança e da proximidade como chaves para a compreensão das dimensões sociais e culturais dos mercados.

Dentro desse contexto, nos estudos agroalimentares e da sociologia rural, temas anteriormente com poucas interfaces - tais como produção, comercialização, consumo, nutrição e saúde - têm sido integrados para melhor compreensão da questão alimentar atual. Daí emerge uma nova abordagem, que tem discutido o desenvolvimento rural a partir dos mercados e das novas formas de produção e consumo de alimentos (Hebink et al., 2014). Nesse campo, os estudos sociológicos têm se ocupado com questões pertinentes às relações de confiança, a estabilização dos mercados e a reprodução de práticas sustentáveis, justas e éticas no interior das sociedades atuais, retomando assim a agenda institucionalista (Niederle \& Wesz Junior, 2018).

Do ponto de vista empírico, os mercados passaram a ser analisados pelo que a literatura internacional tem denominado de cadeias curtas (Gazolla \& Schneider, 2017), redes alimentares alternativas (Goodman et al., 2012), cadeias de valor (Blay-Palmer et al., 2018) ou sistemas descentralizados de abastecimento (Maluf \& Luz, 2018). O ponto comum de todas essas abordagens reside no destaque atribuído à dimensão local dos mercados, suas contribuições 
para a circulação de conhecimentos e práticas tradicionais, desenvolvimento de processos sustentáveis, promoção de inovações e novidades, assim como espaços de sociabilidade e de interconhecimento, que fortalecem os tecidos sociais e territoriais e permitem acesso a alimentos frescos e saudáveis (Cassol \& Niederle, 2019).

Pelo lado da teoria, boa parte dos estudos citados utiliza-se de duas abordagens analíticas principais da sociologia econômica para explicar o papel desempenhado pelos mercados na produção e no consumo sustentável de alimentos: a abordagem das redes sociais e a abordagem de campo. Enquanto a primeira foca nas interações sociais e no conjunto de atores e organizações que se relacionam na construção de novas e diferentes estratégias de comercialização alimentar, a segunda tem como objetivo investigar as "forças sociais" que competem na estruturação de práticas e processos de transação e troca que são estabelecidos entre os atores (Granovetter, 2007; Bourdieu, 2005; Beckert, 2010).

Ambas as abordagens acima explicam as dinâmicas contemporâneas dos mercados agroalimentares, as relações de confiança e proximidade por eles geradas. Porém elas não dão conta em analisar os componentes culturais que também influenciam na tomada de decisões dos atores e na estruturação desses mercados (Carneiro, 2019).

Nesse sentido, este artigo tem como objetivo analisar os mercados agroalimentares contemporâneos a partir de uma perspectiva institucionalista, tendo como foco os valores culturais que são compartilhados pelos atores nas suas práticas interativas de comercialização e consumo de alimentos (Polanyi et al., 1957; Polanyi, 1980). O intuito é demonstrar como a economia se assenta sobre um conjunto de instituições sociais que são responsáveis por dar sentido e significado às ações econômicas dos atores.

Os dados aqui apresentados referem-se à pesquisa realizada anteriormente junto a três mercados agroalimentares brasileiros localizados em distintos estados do país, a saber: a Feira do Pequeno Produtor de Passo Fundo/RS, a Feira Central de Campina Grande/PB e a Feira de Caruaru/PE 1 . A metodologia utilizada foi de cunho qualitativo, fazendo uso do método comparativo entre esses mercados, sendo os dados coletados por meio de 35 entrevistas semiestruturadas com atores-chave (feirantes, agricultores, consumidores, representantes de órgãos municipais, sindicatos etc.), além de análise de documentos e bibliográfica.

$\mathrm{O}$ argumento aqui defendido é o de que os atores sociais, antes de estabelecerem redes de relações e transações econômicas ou posicionarem-se no interior do campo (mercado) econômico, já compartilham um conjunto de valores culturais comuns (instituições) que são os responsáveis por construir os mercados locais nos quais interagem. Ademais, esses valores compartilhados conformam aquilo que a sociologia econômica conceitua como "imersão social da economia", definindo maneiras de agir e negociar próprias dos agentes. É esse processo de imersão que problematizamos e analisamos ao longo deste artigo.

$\mathrm{O}$ artigo divide-se em quatro seções para além dessa introdução. Na primeira seção apresentamos com maiores detalhes a abordagem institucionalista proposta, destacando a importância de estudar os mercados alimentares sob tal perspectiva, contribuindo para ir além das abordagens de rede e de campo e interpretar os mercados alimentares locais.

Na segunda seção, analisam-se os mercados como instituições, destacando-se as escolhas metodológicas de análise dos dados e as distintas formas de imersão social das práticas econômicas que os mercados podem assumir, notadamente quando se analisam mercados que envolvem a oferta de alimentos. Na terceira seção apresentamos o processo de construção social de cada um dos mercados pesquisados, analisando suas origens históricas.

1 Os dados utilizados fazem parte de um estudo mais amplo realizado para a tese de doutoramento de um dos autores. Para mais informações ver Cassol (2018). 
A quarta seção é reservada à análise dos principais valores culturais - ou instituições mobilizados pelos atores na concretização de suas práticas de comercialização e consumo nos mercados: a barganha, a variedade de alimentos, o preço e a qualidade. Finalmente, são apresentadas as considerações finais.

\section{Para além das redes sociais e das estruturas: a importância das instituições para análise dos mercados alimentares locais}

A emergência das análises acerca dos mercados alimentares locais tem privilegiado duas abordagens principais da sociologia econômica para compreensão dos mecanismos de troca e transação de alimentos: as redes sociais e a abordagem de campos.

A abordagem de redes sociais é utilizada para verificar como os mercados alimentares são estruturados a partir da análise dos diferentes atores e organizações diretamente envolvidos em práticas de produção, comercialização e consumo de alimentos, destacando-se as maneiras pelas quais estes interagem e relacionam-se para construir distintos espaços de troca (Goodman et al., 2012). Ao analisar aspectos tais como as características contextuais das trocas, as relações de confiança estabelecidas entre produtores e consumidores, o papel desempenhado por associações e organizações coletivas na construção dos mercados, entre outros, reivindica que os mercados locais encontram-se imersos em redes de relações interpessoais.

Ou seja, o diferencial positivo atribuído aos mercados alimentares reside no fato de que esses espaços são construídos e geridos por meio da interação social que aproxima a diversidade de atores (e suas organizações) a processos de produção e consumo sustentáveis de alimentos. Essas interações é que garantem a estabilidade dos mercados e o acesso à informação (Granovetter, 2007). Portanto, a abordagem de redes sociais atribui às interações sociais o mecanismo essencial de construção dos mercados, sendo que tais espaços - e as práticas de negócio e transação em seu interior - decorrem das relações estabelecidas entre os atores (White, 1981).

De maneira diferente, a abordagem de campo analisa os mercados enquanto "arenas sociais" no interior das quais os atores encontram-se posicionados e disputam por legitimidade e reconhecimento. Dessa forma, essa abordagem insere a dimensão do poder nas análises sobre mercados (Bourdieu, 2005). Na medida em que os atores encontram-se hierarquicamente posicionados nesses espaços, suas interações e trocas respondem a um conjunto de "forças sociais" que atuam na estruturação de práticas de troca e de transação (Beckert, 2010).

Nesse sentido, para a abordagem de campo o foco da análise dos mercados não se encontra nos processos de troca e de transação, mas nas forças sociais que orientam a ação dos atores posicionados no campo econômico (Beckert, 2010; Fligstein, 2001). Essas forças sociais podem ser redes de relações interpessoais, acesso a normas e regras, valores e práticas culturais e outros (Beckert, 2010).

A abordagem dos nested markets que vem sendo desenvolvida para analisar mercados alimentares contemporâneos pode ser interpretada a partir da noção de campo, ainda que seus principais autores não façam tal referência. O grande diferencial dessa abordagem é relacionar os fluxos de mercadorias, informações e valores que constroem os mercados locais sustentáveis com os padrões, normas e regras que reproduzem os mercados convencionais (Ploeg, 2016; Brasil \& Schneider, 2020). Destaca-se que este processo de interação é múltiplo e diverso; um campo de disputas e relações de poder, nos quais práticas e processos alternativos concorrem com práticas e processos convencionais de produção e consumo para a aceitação e legitimação de seus produtos agroalimentares (Grivins \& Tisenkopfs, 2018; Schneider \& Cassol, 2020). 
Apesar das suas qualidades em explicar diferentes aspectos das trocas e dos mercados, ambas as abordagens apresentadas carecem em relação a um aspecto central da orientação das ações econômicas dos atores, especialmente quando inseridos em interações de comercialização e consumo de alimentos locais: a dimensão cultural e valorativa que esses atores compartilham e que orientam previamente suas escolhas.

A análise de redes, por exemplo, apesar de reivindicar a imersão das relações econômicas em aspectos sociais e contextuais, não explica satisfatoriamente como essa imersão é construída assim como as próprias redes são formadas. Por que os atores escolhem participar de determinadas redes e de outras não? Por que algumas redes diferem entre si? Por exemplo, alguns mercados alimentares são construídos sobre dimensões de saúde, enquanto outros sobre dimensões de qualidade ou tradição.

Por sua vez, a abordagem de campo, apesar de inserir a cultura como uma "força social" que opera no interior dos mercados, não problematiza a dimensão dos valores que são trocados pelos atores nesses espaços. O foco é muito mais na estrutura que nas práticas sociais/culturais.

Para sanar essas lacunas, propomos uma análise dos mercados enquanto instituições. Mercados são instituições sociais na medida em que obedecem - poder-se-ia dizer mais apropriadamente que estão imersos - as características locais de produção, comercialização, manuseio e consumo dos alimentos que são orientadas e baseadas nos valores que os atores que atuam na sua construção compartilham. Ou seja, as transações econômicas de troca e comercialização não se orientam e se baseiam apenas em critérios de preço, quantidade e liquidez, mas em valores e normas próprios que regem as interações daqueles que participam nessas trocas e intercâmbios.

Portanto, nosso argumento difere daquele defendido pela abordagem das redes sociais para a qual os mercados decorrem das interações interpessoais estabelecidas e construídas pelos atores, assim como se distancia da abordagem de campo. Defendemos que antes de entrar em rede (conectar-se de maneira interpessoal com outros atores), os agentes compartilham determinados valores culturais contextuais que orientam suas escolhas. São essas escolhas decorrentes dos valores que conformam as redes sociais de interação e de negócio e definem as posições dos atores no interior do campo. Isto é, são esses valores compartilhados os responsáveis pela construção dos mercados.

Nesse sentido, analisamos os mercados sob outra perspectiva, que tem como foco as instituições sociais. Como instituição, definimos o conjunto de valores sociais e culturais (históricos e contextuais) nos quais a economia está situada, e que, por sua vez, definem normas e regras de interação e transação econômica (Polanyi, 1980).

Nosso objetivo é problematizar o processo de imersão social das práticas econômicas no interior dos mercados analisados, demonstrando como esse processo está ligado a um conjunto de instituições (valores) que definem maneiras de agir e negociar dos atores em cada um dos casos. Demonstramos como esse processo de imersão é diverso e heterogêneo, conferindo características específicas aos mercados alimentares.

\section{Os mercados como instituições e os diferentes tipos de imersão}

A análise das instituições sociais possui extenso lastro nos estudos sociológicos. Desde os autores clássicos, esse conceito tem sido definido e mobilizado para explicar a vida em sociedade, especialmente os aspectos relativos à economia e às ações econômicas (Weber, 1991; Durkheim, 2010; Raud, 2005). 
A partir dessas análises, uma multiplicidade de abordagens e definições de instituições foi sendo construída por diferentes teóricos para explicar a economia enquanto um fenômeno social, portanto um tema central para a sociologia (Azevedo, 2016). Reconhecendo tal diversidade, nesse trabalho nos interessa destacar a contribuição de Karl Polanyi (1980) e Polanyi et al. (1957) e sua abordagem institucionalista para pensar os mercados (em especial aqueles que se dedicam a compra e venda de alimentos).

Polanyi é o autor que cunhou o conceito mais utilizado e debatido na sociologia econômica, que foi, e ainda é, apropriado por diferentes intelectuais para analisar e explicar sociologicamente o funcionamento dos mercados. Tal conceito refere-se à ideia de "imersão (embeddedness) social da economia".

Para desenvolver tal ideia, Polanyi parte de algumas premissas. A primeira delas é o reconhecimento de que o social (a sociedade) tem poder de influenciar e orientar o econômico. A segunda refere-se à especificidade histórica atribuída ao capitalismo enquanto sistema único e a sua capacidade em desintegrar os valores e normas sociais tradicionais. A terceira premissa diz respeito a uma visão do mercado e das instituições econômicas como produtos históricos, e, portanto, correspondentes às características sociais e culturais das diferentes épocas. Por fim, Polanyi via a economia enquanto um "processo instituído", ou seja, como resultado das interações substantivas entre o homem e seu meio (social, natural, cultural) e que se traduz na provisão contínua dos meios materiais que permitem a satisfação das necessidades ${ }^{2}$ (Dale, 2011; Polanyi, 1980).

De acordo com ele, o processo econômico se estabelece em dois níveis: "o da atividade interativa entre os seres humanos e seu entorno (que podem ser materiais e sociais); e o da institucionalização deste processo" (Escher \& Schneider, 2011, p. 190). Essa institucionalização nada mais é que o modo de organização do processo econômico ao longo do tempo, isto é, as formas através das quais ele foi integrado pela sociedade.

Assim, Polanyi identificou três formas de integração/prestação econômica presentes ao longo da história, as quais, de maneira combinada, tiveram a função de gerar estabilidade e unidade à economia e às transações econômicas: a reciprocidade, a redistribuição e a troca (mercantil) (Polanyi et al., 1957, Polanyi, 1976, 1980). Ou seja, o autor reivindica a coexistência de diferentes e diversos tipos de troca e de transação ao longo das sociedades, inclusive na capitalista, e que são as responsáveis por manter a sua estabilidade e seu funcionamento ${ }^{3}$.

Portanto, Polanyi evidencia a impossibilidade de a vida social ser gerida apenas pelos mercados e pelo princípio da troca mercantil, afirmando que, apesar de transformar-se ao longo do tempo, a economia sempre esteve imersa em relações sociais e valores culturais ${ }^{4}$.

Nesse sentido, o autor propõe a sua abordagem institucionalista dos fenômenos econômicos e dos mercados. Para ele, a economia consiste em um sistema de relações sociais e normas e regras que os atores compartilham e que são institucionalizadas de maneiras diferentes de

\footnotetext{
2 Em sua época, Polanyi travou intenso debate contra autores que definiam a economia sob uma perspectiva formalista. Para esses teóricos, a economia e o mercado são processos naturais e intrínsecos que decorrem da própria natureza ontológica da sociedade. Nesse sentido, a economia é uma relação entre meios e fins, na qual o indivíduo age de maneira racional na busca de recursos escassos. Contrariamente, a perspectiva substantiva defendida por Polanyi se baseia na visão de que a economia é instituída socialmente através da relação entre o homem e seu meio, sendo a satisfação das necessidades oriunda dessa interação, e não da busca racional por recursos escassos. Mais informações ver Machado (2010).

3 O papel assistencial desenvolvido pelo Estado atualmente, por exemplo, é baseado numa prestação econômica de caráter redistributivo, assim como relações de ajuda mútua e manejo compartilhado de recursos em áreas rurais são pautadas pela reciprocidade (Escher \& Schneider, 2011; Sabourin, 2011).

4 Não há consenso por parte dos estudiosos quanto a essa afirmação de Polanyi. Enquanto alguns identificam um erro do autor ao afirmar que os mercados romperiam com os laços sociais - baseados na noção de des-imersão da economia no capitalismo -, outros atribuem a essa tese um recurso metodológico desenvolvido para explicar a impossibilidade de a economia existir sem sofrer influências sociais e culturais. Maiores informações em (Gemici, 2008; Machado, 2010; Krippner, 2001).
} 
acordo com os contextos e épocas históricas nos quais esses atores encontram-se inseridos. Ao mesmo tempo em que tais regras e valores - ou instituições - impõem constrangimentos e restrições aos atores, também abrem oportunidades a eles (Maucourant \& Plociniczak, 2013, p. 514).

Esta concepção está de acordo com nossa visão sobre os mercados enquanto construções sociais decorrentes de valores e normas sociais/culturais compartilhadas a nível local pelos atores e que estruturam socialmente o espaço no qual a economia encontra-se imersa. A partir dessa definição institucional da economia, assentada na premissa de que quaisquer tipos de transação econômica (e de mercados) encontram-se regulados (imersos) por valores sociais e culturais, é possível interpretar que existam distintos tipos de imersão (DiMaggio \& Louch, 1998).

No caso dos mercados locais que foram estudados neste trabalho, utilizamos essa distinção entre tipos de imersão para verificar empiricamente como as relações econômicas no interior de cada um desses espaços, apesar de possuírem características culturais específicas, são influenciadas por normas e regras mais amplas, que podem entrar em conflito (e modificar) com as práticas culturais tradicionais desses mercados.

A partir dessa definição metodológica propomos dois níveis analíticos que foram articulados para analisar quais os valores culturais mobilizados pelos atores (feirantes e consumidores) nas suas práticas de negócio e transação nos mercados, assim como em que medida valores e normas mais gerais da sociedade influenciam no abandono e/ou proibição de determinadas práticas tradicionais (ver Figura 1).

Nesse sentido, definimos um primeiro nível analítico que se refere às relações socioeconômicas e às práticas culturais no interior de cada uma das feiras pesquisadas. Nesse nível, nos debruçamos sobre os tipos de instituições que regem as práticas culturais e econômicas; as regras sociais de interação e estratégias de negócio; mecanismos de apresentação dos produtos; relações dos feirantes com os consumidores. Este primeiro nível denominamos embeddedness local, no qual predominam os valores sociais e culturais "específicos" (amizade; diversidade; identidade; tradição; qualidade; barganha).

O segundo nível analítico se referiu às relações que as feiras livres mantêm com a sociedade local e os mercados mais amplos, inclusive com os atores do poder público (normas sanitárias, regulamentos, mecanismos de controle, restrição de práticas, incentivos etc.). Esse nível denominamos embeddedness estrutural, assentado em valores "gerais" (competitividade; lucro; eficiência; produtividade; escala; saudabilidade/higiene) ${ }^{5}$. É por meio da interação e disputa entre esses níveis e seus valores que o processo de imersão da economia é construído.

A partir de tais estratégias metodológicas e teóricas, encontramos quatro instituições sociais principais responsáveis pela orientação das práticas de negócio e transação no interior dos três mercados alimentares pesquisados e que foram construídas ao longo dos processos de ocupação dos territórios ${ }^{6}$ nos quais se encontram: a qualidade, a barganha, a variedade de oferta de produtos e o preço.

\footnotetext{
5 Para fins de análise deste artigo, nas seções abaixo discutimos o nível 01 . Ainda que o nível 02 apareça nas falas dos entrevistados - principalmente em relação à exposição e consumo de carnes e queijos -, ele não será analisado de maneira individual.

6 Apesar da riqueza de significados subjacente ao conceito de território, seu uso recorrente, neste artigo, referese à área geográfica e espacial na qual os mercados analisados estão inseridos. Nesse sentido, o território é o espaço em que as relações e interações mercantis transcorrem, materializando-se em disputas, negociações, barganhas e outros, que conformam o modo como o poder é exercido entre os agentes que atuam nesses mercados.
} 

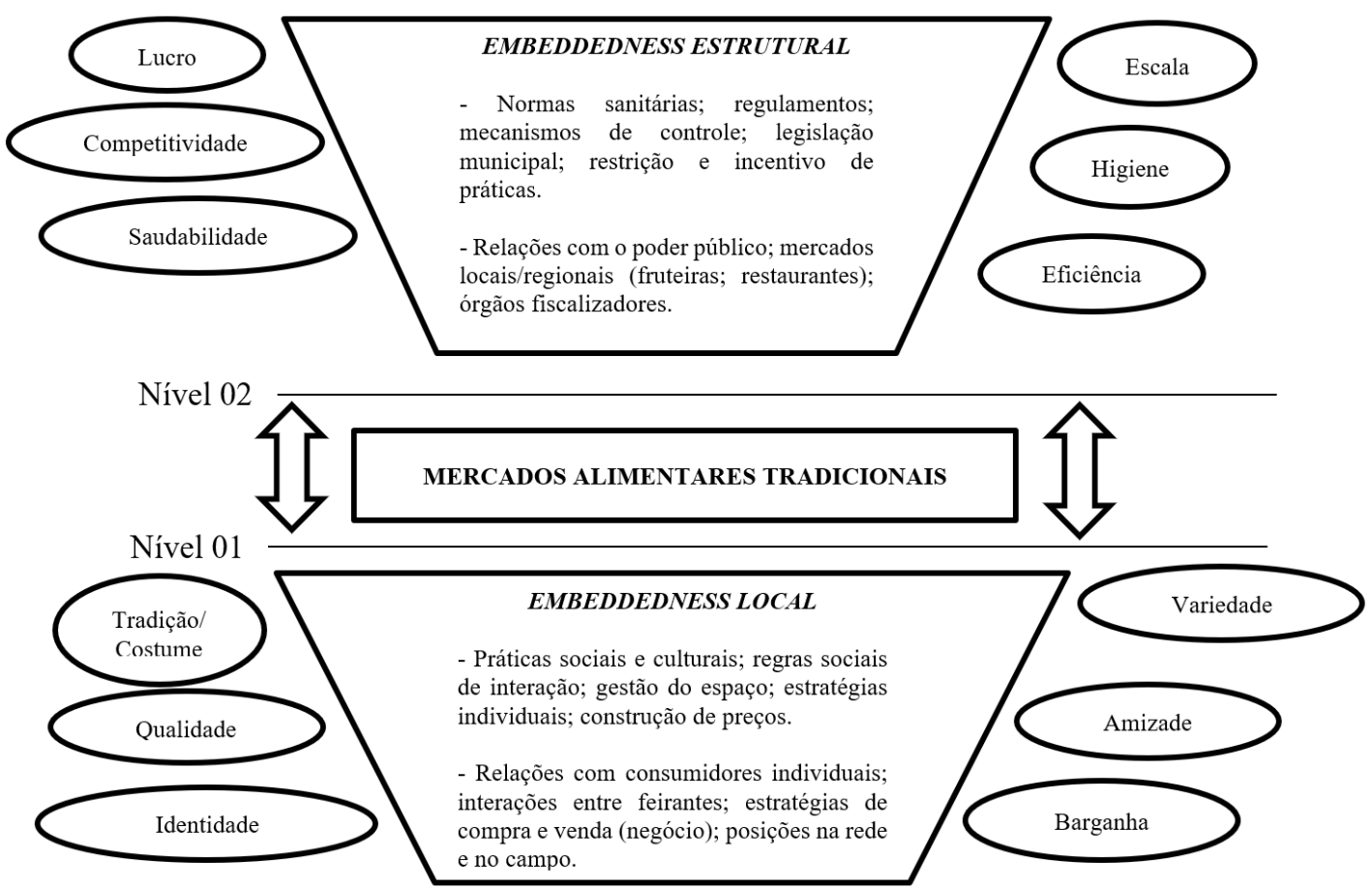

Figura 1 - Níveis analíticos de estruturação dos mercados alimentares analisados. (Fonte: Cassol, 2018, p. 83).

Para compreender melhor esse processo e o papel desempenhado por tais instituições na vida cotidiana dos atores pesquisados, a próxima seção apresenta uma descrição das raízes sócio-históricas dos mercados analisados visando demonstrar o processo de construção social das instituições encontradas.

\section{As raízes sócio-históricas das feiras e a construção social das instituições: 0 ambiente de negócios agrestino e o passado rural comum do Planalto Médio gaúcho}

As feiras-livres nordestinas de Campina Grande, na Paraíba, e Caruaru, em Pernambuco, são dois dos maiores mercados alimentares brasileiros, historicamente presentes na região Agreste e centros extremamente importantes de distribuição e consumo de produtos alimentícios. Essa região situa-se entre a Zona da Mata e o Sertão, cortando inúmeros dos estados nordestinos, sendo considerada "uma zona de transição, com trechos quase tão úmidos como o da Mata e outros tão secos como o do Sertão, alternando-se constantemente e a pouca distância" (Andrade, 1973, p. 25).

Do ponto de vista social e econômico, a ocupação do território agrestino se deu principalmente sobre três atividades e dimensões interligadas e responsáveis por desenvolver características específicas, transformando essa região em um local propício para atividade comercial. Num primeiro momento, a ocupação se deu sobre grandes extensões de terras baseadas na monocultura pecuarista decorrente da divisão de sesmarias (século XVIII), a qual foi substituída por uma "policultura consolidada" (séculos XIX e XX) transformando a região na principal fornecedora de alimentos para o Sertão e a Zona da Mata naquele período (Andrade, 1973).

Essa "transição" para uma agricultura diversificada assentada na produção de gêneros alimentícios consolida o Agreste como uma área de comércio (alimentar) e de negócios. 
Basicamente, o processo de ocupação do território baseou-se na associação entre as atividades de criação de gado, a plantação de algodão e a cultura de subsistência.

Essas três atividades estão fortemente ligadas ao desenvolvimento das feiras e mercados alimentares da região. Enquanto a criação de gado acabou desenvolvendo feiras de gado e de farinha, o declínio da produção canavieira e dos engenhos liberou mão de obra para a agricultura de subsistência (policultora) e para o comércio, consolidando feiras alimentares regionais que passaram a abastecer as cidades nordestinas e absorver trabalhadores e comerciantes, desenvolvendo o comércio urbano na região (Mott, 1975; Garcia, 1984; Palmeira, 2014).

Esse contexto peculiar de transição geográfica e social confere à região Agreste características de entreposto comercial que resultam em maneiras de agir e negociar sob as quais as ações econômicas dos atores pesquisados estão imersas. Mais do que isso, ambas as feiras pesquisadas possuem origem histórica comum, que se confundem com a fundação das duas cidades nas quais se encontram, tendo origens parecidas.

A Feira Central de Campina Grande surge no processo de ocupação do território paraibano, especificamente da região da Borborema. Essa ocupação se deu através do trânsito de comerciantes e viajantes que se deslocavam entre o Sertão e o litoral paraibano levando e trazendo o gado e inúmeras outras mercadorias para comercialização nestas áreas (Almeida, 1978). Como no território de Campina havia um grande açude, ideal para dar de beber ao gado e descansar da longa viagem, foi se desenvolvendo ali um comércio incipiente das mercadorias e produtos alimentícios que os viajantes levavam consigo, consolidando um ponto de comércio e parada na região e dando origem a uma Feira (Almeida, 1978).

Dessa forma, a Feira Central de Campina Grande sempre esteve presente no território e no imaginário social de seus habitantes, sendo que os campinenses atribuem a própria existência da cidade como consequência da feira ${ }^{7}$. Além disso, seu desenvolvimento inicial está intimamente ligado ao papel desempenhado pela população sertaneja (agricultores familiares), que tinha na farinha de mandioca o principal produto que era comercializado com os almocreves e boiadeiros que se deslocavam entre o litoral e o Sertão, e que recorriam à Feira de Campina para adquirir seus suprimentos de viagem (principalmente alimentos) (Albuquerque, 2003).

Atualmente, a feira conta com cerca de 2.805 pontos de venda. Desse total, 347 comercializam carnes (esses feirantes estão localizados no interior do mercado público, construído em 1925, que recebeu uma cobertura e algumas melhorias nos anos 1990), 833 vendem frutas e verduras, 279 são comerciantes de confecções, 207 produtos de alimentação (lanchonetes, bolos, tapioca e outros), 140 comercializam produtos de estiva e cereal e 57 são vendedores de queijo. Os 942 pontos restantes dividem-se na comercialização de uma ampla variedade de produtos ${ }^{8}$.

Para este trabalho, os dados coletados referem-se aos feirantes que comercializam alimentos, notadamente frutas, legumes e verduras (FLVs), carnes e peixes, queijos e derivados. Apesar de a Feira Central de Campina Grande ocorrer todos os dias da semana (exceto aos domingos), o dia considerado "de feira" refere-se ao sábado, justamente quando o contingente de feirantes pesquisados é mais numeroso.

Por sua vez, a Feira de Caruaru possui origem parecida com a da Feira Central de Campina Grande. Por também situar-se entre o litoral e o Sertão, a cidade de Caruaru começa a ser ocupada por volta do ano de 1756 com a expulsão dos índios cariris e a divisão das terras da região em sesmarias. Uma dessas áreas fica sob a responsabilidade da família Rodrigues de

\footnotetext{
7 Vale registrar que a ocupação do território de Campina Grande remete ao ano de 1697. Por sua vez, é elevada à categoria de cidade no ano de 1864.

8 Estes dados fazem parte de projeto executivo levado a cabo pela Seplan (Secretaria de Planejamento), no ano de 2013, para Requalificação da Feira Central e do Mercado Público, e não estão publicados. Tal projeto, que previa a revitalização da Feira Central e do Mercado Público através de projeto arquitetônico, da construção de novas bancas e da readequação dos feirantes para outros locais mais bem organizados, apesar de iniciado não teve sua conclusão efetivada, por diversos motivos aqui não explorados. Para maiores informações consultar Cassol (2018).
} 
Jesus, que funda a Fazenda Caruru e, em 1782, constrói no interior da propriedade uma capela em homenagem a Nossa Senhora da Conceição, tornando a fazenda não apenas um ponto de apoio aos viajantes, mas também local de encontro e reunião da população nos dias de celebração e missa. Ao final de tais celebrações, a população aproveitava para reunir-se e trocar produtos de variadas espécies e gêneros alimentícios, conformando um pequeno comércio de trocas que foi desenvolvendo-se e acolhendo um pequeno povoado que começou a instalar-se nos arredores da capela. É deste processo que surgem a feira e a cidade de Caruaru9 (Araújo, 2011).

Hoje em dia, estima-se que a Feira de Caruaru ocupe por volta de 21.000 feirantes. Esse total de pessoas ocupadas refere-se às diferentes feiras que fazem parte da Feira de Caruaru e que alternam entre os dias da semana seus dias de maior importância ${ }^{10}$. Em relação à Feira Livre (também chamada "Feira Tradicional") - objeto deste estudo - que ocorre aos sábados e congrega os feirantes de FLVs, carnes, peixes, queijos e derivados, estima-se aproximadamente 1.915 feirantes cadastrados (Cassol, 2018). A alusão à Feira de Caruaru, neste trabalho, referese a esse universo da Feira Livre acima descrito.

Além dessas origens históricas comuns, tais mercados se caracterizam pela diversidade de feirantes e de circuitos de comércios desenvolvidos para que os alimentos possam ser comercializados em seu interior ${ }^{11}$. Cada uma das feiras abarca desde pequenos agricultores que a elas se dirigem uma vez por semana (aos sábados), para comercializar os alimentos que produzem, até pequenos e médios comerciantes que não são produtores, mas que adquirem seus produtos em centrais de abastecimento locais (Empresa Paraibana de Abastecimento e Serviços Agrícolas - Empasa e Central de Abastecimento de Caruaru - Ceaca).

Portanto, esses dois mercados alimentares tradicionais nascem imersos em valores sociais e culturais específicos da região Agreste nordestina e que regulam a vida econômica dos atores. Conforme veremos na próxima seção, as práticas de consumo e comércio no interior da Feira Central de Campina Grande e da Feira de Caruaru encontram-se imersas em quatro instituições sociais: a variedade de produtos ofertada (ligada ao número expressivo de feirantes e seus circuitos de comércio), a qualidade atribuída aos alimentos (decorrente da reprodução de práticas tradicionais de exposição e consumo, notadamente as carnes e queijos), a possibilidade de pechinchar e barganhar no momento da compra (ligada à vocação de "fazer negócio" da região Agreste) e os preços baixos dos alimentos comercializados nesses espaços (característica das feiras livres).

Finalmente cabe destacar uma diferença extremamente importante entre as duas feiras nordestinas e que se refere ao controle e atuação do Estado e das exigências de cumprimento de regras e normas de higiene e sanidade entre os feirantes desses mercados.

Enquanto em Campina Grande não há quaisquer taxas que têm de ser pagas ao poder público para comercialização e participação na feira - aumentando seu grau de informalidade e de relações de barganha entre consumidores e feirantes -, na Feira de Caruaru os feirantes têm de pagar uma taxa semanal de "uso do solo" e um alvará anual de funcionamento12. Em

\footnotetext{
9 A elevação de Caruaru à condição de cidade se deu, apenas, em 1857.

${ }^{10}$ Cabe registrar que, diferentemente de Campina Grande, onde os "setores dentro da feira" encontram-se misturados, em Caruaru há uma divisão concreta entre os setores, sendo que a chamada Feira de Caruaru é composta pela Feira do Artesanato, Feira do Paraguai, Feira Livre (Tradicional) e a Feira da Sulanca, que é um grande polo de confecções da região, atraindo muitos comerciantes nas segundas-feiras.

${ }^{11}$ Outro ponto em comum é que ambas as feiras são permanentes e ocorrem de segunda a sábado, todas as semanas. Porém, o dia considerado "de feira" é o sábado, dia no qual mais pessoas comercializam e consomem através desses mercados, principalmente em relação aos feirantes agricultores.

$12 \mathrm{Na}$ época da pesquisa, os valores cobrados pela prefeitura eram de $\mathrm{R} \$ 15,00$ por semana para cada banco da feira e cerca de $\mathrm{R} \$ 56,48$ por ano de alvará de funcionamento. Esses valores podem variar de acordo com o tamanho do banco da feira, que não são padronizados, assim como com a localização da feira (em feiras livres de bairro as taxas são menores). Estimou-se à época uma arrecadação municipal mensal de R\$931 mil com as taxas cobradas junto a todas as feiras da cidade.
} 
termos práticos, isso acaba resultando em uma menor propensão a fazer negócio e barganhar no interior da Feira de Caruaru, visto que o controle e as exigências sanitárias são maiores.

Contudo, em ambos os mercados são toleradas e reproduzidas práticas tradicionais de exposição e consumo de alimentos - vistas como positivas pelos consumidores - e que vão de encontro às legislações sanitárias.

Nesse sentido, reforça-se o argumento defendido neste trabalho, que atribui ao prévio compartilhamento de instituições sociais entre os atores - que são formadas historicamente e transmitidas pela cultura - como responsáveis por colocar esses atores em processos de interação (redes sociais). Nos mercados alimentares agrestinos, feirantes e consumidores compartilham uma visão de mundo arraigada em representações que veem as feiras como um reflexo da identidade social e cultural do nordestino. Essa identidade é reforçada na medida em que são mobilizadas e compartilhadas instituições sociais específicas que orientam as práticas econômicas.

A Feira do Pequeno Produtor de Passo Fundo possui origem distinta das feiras nordestinas. Localizada na região do Planalto Médio gaúcho, esse mercado surge como uma alternativa à produção de grãos, especialmente o monocultivo de soja, a partir dos anos 1970.

A região do Planalto Médio inicialmente foi habitada por população indígena (principalmente da etnia Kaingang) produtora de gêneros alimentícios (milho e feijão), a qual foi expulsa de suas terras com a chegada dos bandeirantes paulistas, que estabeleceram o comércio de gado gaúcho em direção a São Paulo como uma das principais atividades comerciais a partir do século XVII. Assim sendo, a cidade de Passo Fundo também se origina de um território de passagem e parada dos tropeiros paulistas, que, ao preferir transportar o gado durante o dia para evitar ataques indígenas, escolhiam o "passo fundo" - região alta, plana e com bom acesso a água - para pernoitar e descansar (Miranda \& Machado, 2005).

Em meados do século XIX chegam à região inúmeros imigrantes europeus que passam a adotar um "sistema colonial" de produção, baseado na policultura e na produção de gêneros alimentícios (milho, feijão, mandioca, batata) em pequenas e médias extensões de terra (Fritz Filho \& Miguel, 2008). Porém, por diversos motivos como a falta de terras, o aumento demográfico e a dificuldade de reprodução dos agroecossistemas que sustentavam esse modelo, a agricultura colonial entra em crise a partir de 1930, sendo substituída por um modelo de agricultura mais especializado e com melhores condições de infraestrutura e tecnologia, dando início à predominância de cultivos comerciais de grãos (commodities) na região (principalmente a soja).

É nesse contexto histórico de formação ligada ao comércio de gado, aos imigrantes europeus e seu modo de vida colonial ${ }^{13}$ baseado na produção de gêneros alimentícios tradicionais e no crescimento de culturas comerciais de grãos voltadas à exportação que a região do Planalto Médio gaúcho se desenvolve ao longo dos anos, consolidando características específicas relacionadas ao comércio de alimentos.

A Feira do Pequeno Produtor de Passo Fundo tem sua origem remetida à iniciativa de alguns agricultores da cidade que, inconformados com a situação da agricultura à época (1975), tal como o aumento dos custos de produção de grãos e a queda da renda advinda dessa produção, decidiram começar a comercializar seus alimentos diretamente aos consumidores, na região central do município. Apesar de pequena em seu início, a feira foi se desenvolvendo e agregando um conjunto de atores e entidades que passaram a sustentá-la e geri-la, construindo uma rede de comércio atualmente consolidada.

${ }^{13}$ Conforme Schneider (1999, p. 21), o modo de vida colonial pode ser definido como "uma forma de produzir e uma forma de sociabilidade, implementada pelos colonos, configurando uma estrutura social e econômica [próprias]". 
Assim, a feira gradualmente vai melhorando suas condições de infraestrutura, passando da frente da praça da igreja para a antiga estação férrea do município nos anos 1980, sendo recentemente transferida (2016) para um prédio moderno e próprio também no centro da cidade. Essa melhoria das condições de infraestrutura resulta no abandono gradual de algumas práticas tradicionais, sendo os alimentos e a sua exposição cada vez mais padronizados e conectados com exigências sanitárias.

Todo esse processo de construção social desse mercado deu-se a partir do estabelecimento de uma extensa rede de atores e organizações, que vão desde a Associação dos Feirantes (órgão criado em 1996 e responsável pela gestão do espaço), o Sindicato dos Trabalhadores Rurais - responsável pela prestação de serviços e orientações aos agricultores, a Emater do município e a Prefeitura Municipal, que era a responsável pela gestão da feira e que após a criação da Associação dos Feirantes tem como papel fiscalizar a qualidade e a higiene dos produtos vendidos.

Basicamente, os alimentos vendidos são produtos locais, produzidos no entorno do município e em cidades lindeiras, mas que possuem características regionais bastante acentuadas e conectadas à agricultura colonial. Atualmente a feira é realizada nas segundas e quartas-feiras da semana no período da tarde e nos sábados pela manhã. São 74 feirantes que participam da feira, sendo estes pequenos agricultores residentes na zona rural do município (68 feirantes), que produzem alimentos sazonais e utilizam técnicas e conhecimentos tradicionais ligados à cultura e às origens étnicas do local, e pequenos comerciantes que não são produtores (6 feirantes), mas que compram seus produtos de outros atores e regiões e comercializam na feira.

A introdução desses feirantes comerciantes remete às origens da feira, quando os agricultores que a fundaram perceberam a incapacidade de produzir gêneros alimentícios demandados pela população (notadamente frutas), convidando conhecidos comerciantes para também comercializarem no espaço da feira. A ressalva feita à época foi de que estes vendessem apenas aquilo que não fosse produzido e ofertado pelos feirantes agricultores. Tais comerciantes passaram a ser denominados localmente como fruteiros.

Essa divisão entre feirantes agricultores e fruteiros tem gerado conflitos no interior da Feira do Pequeno Produtor. Com o passar dos anos e a consolidação da atuação dos fruteiros, esses deixaram de cumprir o acordo tácito de apenas comercializar produtos exógenos à região e não produzidos pelos agricultores, gerando uma competição vista pelos feirantes produtores como desleal. Essa percepção era mais forte até recentemente, pois os preços cobrados pelos produtos na feira seguiam uma norma estabelecida entre as entidades que a compõem de que os produtos ofertados deveriam seguir uma tabela, sendo comercializados por um valor $20 \%$ menor que a média de preço desses produtos vendidos em outros mercados da cidade (fruteiras, supermercados, minimercados etc.).

Esse levantamento de preços era realizado por um fiscal da prefeitura que todo mês verificava os preços cobrados por produtos comercializados na Feira do Produtor em outros mercados da cidade, calculava a sua média e afixava no interior da feira uma tabela de preços que deveria ser seguida pelos feirantes (e que era visível aos consumidores).

Segundo os atores entrevistados, essa prática vigeu até 2014, quando a tabela foi abandonada. Os motivos para isso foram, primeiro, o fato de que os fruteiros tiravam vantagem da tabela por não sofrerem com eventuais perdas de produtos decorrentes de intempéries climáticas que afetam a produção (como períodos de estiagem no verão ou geada no inverno) pois compram seus produtos em centrais atacadistas e, por isso, podem suprir a demanda dos consumidores o ano todo. Em segundo lugar o abandono do tabelamento de preços visou privilegiar a qualidade dos alimentos ofertados. De acordo com os entrevistados, a exigência de 
comercializar a preços mais baixos desestimulava os feirantes a buscar qualidade na produção, pois independentemente dessa o produto não poderia ser vendido a um preço maior que aquele encontrado na tabela.

Além dessa transformação em relação à construção dos preços - que veremos adiante não é percebida pelos consumidores, os quais seguem atribuindo a esse mercado um preço justo aos seus produtos -, outra mudança recente se refere ao maior controle no cumprimento do estatuto da associação para participação na feira. Dentre os diversos requisitos exigidos, o enquadramento na Lei da Agricultura Familiar passou a ser exigido para novos feirantes, assim como a adequação destes a práticas de higiene e limpeza.

Essas mudanças encontram correspondência nas práticas adotadas pelo poder público, que proibiu no ano de 2009 a comercialização de leite cru em garrafas pet no interior da feira, deixando desapontados muitos feirantes e, principalmente, consumidores. Outro exemplo da crescente exigência à adequação de normas sanitárias refere-se ao aumento da fiscalização dos produtos e à apreensão daqueles que não possuem selos de registro e inspeção (tais como queijos e derivados).

Portanto, é possível identificar como o mercado da Feira do Pequeno Produtor possui algumas diferenças importantes em relação às feiras nordestinas. Em primeiro lugar, a origem desse mercado está atrelada ao resgate da agricultura "colonial" e da comercialização de gêneros alimentícios locais, que passam a ser vistos como uma alternativa ao modelo vigente de produção de grãos. Em segundo lugar, desde seu início a feira conta com diversas entidades do poder público que atuam na sua regulação, aumentando as exigências sanitárias e proibindo algumas práticas tradicionais, o que não ocorre nas feiras nordestinas.

Finalmente, a busca pelos produtos da feira pelos consumidores justifica-se por meio de três instituições principais: a origem rural dos produtos (valorizada através de uma representação social que distingue positivamente o modo de vida "colonial" ou "da roça"); a qualidade (relacionada ao "frescor" dos alimentos); e os modos tradicionais de produção (também ligados à agricultura colonial e assentados na crença de que os produtos encontrados na feira possuem menos agrotóxicos porque são produzidos de maneira familiar/artesanal).

Por outro lado, a barganha, instituição presente e reproduzida nas feiras nordestinas, não aparece como elemento ordenador das transações econômicas na Feira de Passo Fundo. Pelo contrário, o hábito de pedir descontos e pechinchar os preços é visto de maneira negativa pelos atores, que consideram uma quebra de confiança na interação comercial quando essa prática se torna recorrente.

\section{A imersão social dos mercados alimentares locais: variedade, qualidade, preço e barganha}

A partir da análise histórica da formação dos mercados pesquisados e das características sociais e culturais de ocupação e desenvolvimento de seus territórios, identificamos distintos padrões de imersão econômica - instituições sociais - responsáveis não apenas por estabelecer redes de comércio e transação entre os atores, mas também orientar as maneiras por meio das quais esses atores negociam, como os alimentos são manipulados, o que as pessoas valorizam e por que escolhem tais mercados para abastecerem-se cotidianamente. Identificamos um conjunto de valores culturais que são compartilhados localmente pelos atores e que definem Normas e regras sociais responsáveis por construir seus mercados, reproduzi-los e legitimálos frente a outros espaços. Esses valores, por sua vez, definem diferentes tipos de imersão (Polanyi, 1980; DiMaggio \& Louch, 1998). 
Para os casos aqui analisados, essa imersão na qual as práticas de negócio e transação assentam-se diz respeito a quatro instituições principais. Cada uma dessas instituições é definida e analisada abaixo de maneira separada, porém é necessário destacar que na vida econômica cotidiana dos atores elas encontram-se em interação, sendo mobilizadas de maneira conjunta para justificar as práticas de consumo e de comércio em cada um dos mercados, muitas vezes sendo sobrepostas umas às outras ${ }^{14}$.

A primeira instituição encontrada e que explica a reprodução dos mercados analisados refere-se à variedade de produtos ofertados. Nas feiras nordestinas, é visível a identificação de feirantes e consumidores com a cultura regional através da participação nas feiras de Caruaru e de Campina Grande. Ambas as feiras são vistas como locais nos quais é possível "encontrar de tudo", desde artigos de alimentação (FLVs) até artigos e produtos antigos quase não mais encontrados em outros mercados (especialmente ferragens, artigos domésticos e eletrônicos obsoletos). Ou seja, as feiras mantêm no imaginário da população um significado simbólico atrelado à tradição de existência destes mercados.

Do ponto de vista das práticas de comércio, os feirantes utilizam-se desse componente da variedade como uma estratégia para atrair consumidores e diversificar suas ofertas de produtos. Isso é feito por meio da disposição dos produtos nas bancas, que são selecionados e distribuídos de modo que os consumidores percebam visualmente a diversidade presente em cada uma das bancas.

Em relação aos consumidores, estes demonstram atração pelas feiras pelo fato de que elas representam a tradição comercial das cidades. Essa tradição confere aos produtos ofertados maior autenticidade e qualidade e reforça o caráter tradicional desses mercados.

Isso fica claro na fala de uma das consumidoras entrevistadas quando questionada sobre os motivos de as pessoas virem à Feira Central de Campina Grande:

(...) lá ela acha tudo, mas tudo mesmo. Quando se fala tudo, é tudo que uma pessoa necessita. (...). Na feira eu consumo o meu casamento, na feira eu consumo pra festa do meu filho, na feira eu consumo até pra um... uma cerimônia fúnebre. (...) aqui na feira a gente tem hortifrúti, a gente tem açougue, a gente tem vestuário, a gente tem cama, mesa e banho... aí a gente tem temperos, a gente tem leguminosas, a gente tem semente... a gente tem uma variedade de coisas aqui (...). (Entrevista 13, consumidora, estudante, 43 anos. Consome na feira desde 1992) (Cassol, 2018, p. 169).

No caso da Feira do Pequeno Produtor de Passo Fundo, de modo diferente, a busca dos produtos desse mercado advém do fato de serem produzidos pela agricultura familiar, destacando a valorização social dos "colonos" como a principal motivação. Claramente, essa justificativa está ligada ao contexto de formação da cidade, que teve na imigração europeia e na "agricultura colonial" um de seus pilares. Por isso, as justificações de consumo na Feira do Pequeno Produtor encontram-se vinculadas às origens rurais dos seus produtos.

$\mathrm{Na}$ fala de um dos consumidores, essa motivação ligada às características "familiares" e "coloniais" dos produtos é explícita.

[Eu venho na feira] primeiro pela qualidade dos produtos, que são de uma procedência muito boa. E eu tenho observado nesta feira que os colonos são muito caprichosos né, os produtores têm um zelo especial pelos produtos, e outra pra valorizar essa gente, porque sem eles nós não teríamos comida em cima da mesa, não é verdade?(...) então aí a necessidade da gente comprar do colono e de valorizar ele. (Entrevista 35, consumidor, 68 anos, comerciante. Consome na feira desde seu início) (Cassol, 2018, p. 173).

\footnotetext{
14 Do mesmo modo, a escolha das quatro instituições analisadas não implica assumir que não existam outros valores que estejam orientando as ações dos atores (feirantes e consumidores) em cada um dos mercados analisados, apenas que foram essas instituições que apareceram de maneira mais relevante no momento em que a pesquisa e a coleta de dados foram realizadas.
} 
Percebe-se como a origem rural valorizada e compartilhada pelos atores é vista como positiva, que atribui qualidade aos alimentos ofertados. Essa representação social advém do passado rural comum compartilhado entre feirantes e consumidores, sendo que muitos destes têm origens rurais vinculadas à agricultura familiar. Portanto, comprar na Feira do Pequeno Produtor é materializar esse passado comum, positivo, valorizando o modo de vida "colonial".

A segunda instituição presente na organização e gestão dos mercados pesquisados refere-se aos preços cobrados pelos produtos. Em todos os três mercados pesquisados, as percepções em torno dos preços são de que estes são mais baratos nas feiras, principalmente se levada em conta a qualidade que apresentam. Por isso, os atores buscam esses mercados porque neles é possível encontrar produtos com preços baixos e, ainda, adquiri-los de maneira tradicional por meio de relações de sociabilidade que não são encontradas em outros espaços.

De acordo com o relato de consumidor entrevistado na Feira de Caruaru, preço e qualidade estão conectados nas suas escolhas de consumo de tais mercados.

Eu acho que são vários motivos, mas eu vou elencar dois. Eu acho que é a questão da qualidade mesmo, dos
produtos, porque lá a gente elege mesmo os de mais qualidade, e também a questão do preço, ele se torna
mais acessível. Por exemplo, se você considerar que numa feira de supermercado o quilo da batatinha $R \$ 10,00$,
lá você vai poder comprar por $R \$ 5,00$, por exemplo. Então eu acho que dado o poder aquisitivo de cada um,
se torna menos impactante a compra na feira. Então eu acho que é por aí... preço e a qualidade. (Entrevista
14. Consumidor, 28 anos, assistente social. Consome na feira há 10 anos) (Cassol, 2018, p. 177).

No caso da Feira de Passo Fundo, apesar do abandono do tabelamento de preços realizado recentemente, os consumidores seguem percebendo os preços ofertados como mais em conta que os encontrados em outros locais. Segundo um dos consumidores entrevistados,

Não tem mais [a tabela], mas ainda, se tu for ver assim, comparando com o mercado, ou mesmo em outras feiras ali... fruteiras... ainda se torna mais barato. Porque a maior parte dos outros produtores eles trazem de fora, das outras feiras... mas aqui não, aqui já é direto daqui mesmo, colhe num dia e já vende no outro. (Entrevista 31, consumidor, agricultor aposentado, 63 anos. Consome na feira há cerca de 15 anos) (Cassol, 2018, p. 185).

Portanto, é possível perceber como preço e qualidade se misturam nas justificativas de consumo dos atores, contribuindo para a valorização e reprodução dos mercados. Esse ponto em comum em torno dos preços se deve à natureza das feiras, que, apesar de se encontrarem em contextos culturais distintos, possuem dinâmicas de funcionamento e gestão que não diferem significativamente entre si, somente quando comparadas a outros mercados alimentares.

A terceira instituição na qual a economia encontra-se imersa no interior dos mercados analisados é justamente a qualidade. Conforme atestam diversos estudos, a qualidade é um processo multidimensional no qual objetivos, significados e valores são confrontados na sua construção (Allaire, 2012; Callon et al., 2012). A qualidade, nesse sentido, deriva de um conjunto de valores que não necessariamente estão presentes fisicamente nos produtos, mas que dependem do contexto cultural e social no qual o indivíduo encontra-se inserido.

Nos casos das feiras pesquisadas, a qualidade alimentar atribuída aos alimentos nelas comercializados refere-se ao maior "frescor" dos produtos (pois vendidos em sua maioria de maneira direta), à origem dos alimentos (culinária regional nas feiras nordestinas e origem rural e familiar na Feira do Pequeno Produtor) e finalmente a possibilidade de encontrar produtos que são manuseados ou produzidos de modo tradicional e artesanal. Essa última dimensão vale a pena ser analisada mais de perto.

Nas feiras de Campina Grande e de Caruaru, a valorização de práticas tradicionais de consumo é considerada um fator cultural positivo e diferencial dos dois mercados. Isso é bastante evidente quando analisados os casos das carnes e dos queijos ofertados em ambas as feiras. De acordo com os consumidores, nesses dois espaços é possível encontrar "boi quente" 
e "queijo fresco", isto é, carnes que não passaram por processo de congelamento e queijos processados artesanalmente. Em relação às carnes "quentes" o fato de elas não terem sido congeladas atesta para os consumidores que sua procedência é regional, já que uma carne não conseguiria conservar-se vindo de uma região distante se não fosse congelada. Ademais, o fato de essas mesmas carnes serem expostas ao ar livre nas feiras - e não em câmaras frias - permite que os consumidores possam reproduzir práticas de consumo tradicionais e antepassadas, como tocar e cheirar a carne para atestar sua qualidade ${ }^{15}$.

Essas práticas, toleradas em que pese legislações formais em contrário (embeddedness estrutura), demonstram como a economia e as transações estabelecidas entre os atores no interior das feiras nordestinas estão imersas em valores culturais regionais (embeddedness local), que são reproduzidos nesses espaços. Uma das consumidoras entrevistadas deixa claro suas motivações de consumo e a escolha da feira de Caruaru pela possibilidade de nela reproduzir práticas tradicionais de consumo:

Pronto, a carne é uma carne que você compra fresquinha, que é fiscalizada pela Anvisa, que é nova, enfim... é visível você ver a qualidade da carne. Não tem como se esconder se está estragada ou coisa do tipo. [E ainda] eu costumo apertar, cheirar, principalmente cheirar a carne, pra saber se ela tá de boa qualidade. (Entrevista 14. Consumidor, 28 anos, assistente social. Consome na feira há 10 anos) (Cassol, 2018, p. 211).

No caso de Passo Fundo, a qualidade dos produtos é atribuída ao modo de produção familiar/ artesanal, visto como mais saudável e, acima de tudo, vinculada às tradições e hábitos regionais expressos na "agricultura colonial". Apesar de a grande maioria dos feirantes produzirem seus alimentos de maneira convencional, fazendo uso de agrotóxicos, há uma crença entre os consumidores de que esses produtos são administrados e utilizados de modo responsável, com maior "cuidado", justamente porque quem os administra são agricultores familiares.

Essa crença do "cuidado" torna-se um atributo de qualidade dos produtos ofertados nesse mercado, gerando laços de confiança que reforçam e legitimam a agricultura familiar - e seus modos de produção e de vida - como fonte de alimentos seguros e de qualidade. Nas palavras de um dos consumidores entrevistados,

Eu acho que um produto de qualidade, além de uma boa apresentação que tem, ser um produto bonito, né, é a qualidade também de não ter... esse pessoal, ele não usa muito agrotóxico né (...). Quando é o pequeno produzindo, ele usa menos isso. Então pra mim isso é qualidade, quanto menos agrotóxico tiver hoje, é mais qualidade. (Entrevista 32, consumidor, 54 anos, professor. Consome na feira há 20 anos) (Cassol, 2018, p. 221).

Finalmente, a quarta instituição na qual a economia encontra-se imersa nos mercados analisados é a barganha. Essa instituição demonstra como o contexto cultural das regiões interfere diretamente nas transações e no modo como os atores relacionam-se economicamente. Conforme visto na seção anterior, a região Agreste nordestina se caracteriza como um "ambiente de negócios", um entreposto entre o litoral e o Sertão e que sempre os abasteceu de gêneros alimentícios. Diferentemente, na região de Passo Fundo desenvolveu-se uma agricultura colonial que depois foi substituída pela agricultura comercial exportadora de commodities, não desenvolvendo no território a mesma propensão aos negócios ou ao comércio.

Nesse sentido, enquanto nas feiras nordestinas a barganha e a pechincha são normas sociais mobilizadas nas interações econômicas em seu interior, na feira de Passo Fundo pedir

15 Tais práticas são proibidas do ponto de vista legal, sendo que tanto a legislação municipal quanto a federal proíbem a comercialização de produtos de origem animal sem refrigeração. Contudo, seja em Campina Grande ou Caruaru, elas seguem sendo toleradas por constituírem-se como práticas culturais que são largamente reproduzidas pelos atores. Inclusive alguns feirantes relataram terem investido na compra de câmaras frias para exposição e conservação de seus produtos, mas que tiveram queda significativa no volume de vendas, já que a carne refrigerada é vista como de menor qualidade. 
descontos ou reclamar dos preços é visto como algo negativo, capaz de romper a confiança nas transações e que deve ser evitado.

Nas feiras de Campina Grande e Caruaru, é comum visualizar consumidores e feirantes negociando abertamente o preço dos produtos, inclusive ambos admitindo que o preço inicial oferecido pelos alimentos seja maior e não equivalente à qualidade da mercadoria. Tanto feirantes quanto consumidores sabem disso de antemão, o que estabelece uma propensão coletiva à barganha, para que nenhum dos atores sinta-se prejudicado. Nas palavras de uma feirante da Feira Central de Campina Grande é possível perceber como a barganha ocorre na prática. Segundo ele,

Ah, aqui é demais [barganha]! Centavos... eu já cansei de contar os centavos que eu já perdi... 30 centavos, 20 centavos, 50 centavos, ah... quando dá $R \$ 10,50$, eles dizem, "dá $R \$ 10,00$ mesmo", e eu digo "é". Então eu acho que eles procuram a feira por isso também, porque ali no supermercado é tudo na máquina, até 20 centavos você paga... e aqui não, aqui eles barganham mesmo. (...) aí eu prefiro o cliente do que os 50 ou os 30 centavos. (Entrevista 10. Feirante comerciante de queijos e doces, 38 anos. Trabalha na feira há 22 anos) (Cassol, 2018, p. 190).

Podemos perceber na fala acima como a barganha nas feiras nordestinas não possui apenas um caráter utilitário e mercantil. Ela é uma norma social e cultural - uma instituição - que já se encontra pressuposta antes que a interação econômica ocorra. Ou seja, já se espera do ator com o qual se transaciona certo grau de negociação e de pechincha, que reforça os laços entre si e gera confiança (Polanyi, 1980). Essa sociabilidade assentada na "negociata" atrai consumidores e reproduz modos de ação econômica dos feirantes, diferenciando as feiras de outros mercados alimentares nos quais não é possível negociar (feiras agroecológicas ou supermercados, por exemplo).

Contrariamente, no caso da Feira do Pequeno Produtor de Passo Fundo, a tentativa de negociar os preços ofertados pelos feirantes é vista como uma ação negativa, uma afronta ao agricultor familiar que tanto batalha para produzir o alimento que está comercializando. Por parte dos feirantes, estes também não veem com bons olhos os consumidores que recorrentemente pedem descontos ou reclamam dos preços, indicando que essa ação, na verdade, está colocando em dúvida a qualidade dos seus alimentos ou até mesmo a sua capacidade enquanto agricultor.

Isso ocorre porque a maneira culturalmente estabelecida ao longo do tempo de transacionar nesse território está conectada às origens rurais e a valorização dos modos de vida e de produção "coloniais", que tem na agricultura familiar - e na Feira do Pequeno Produtor - sua materialização atual. No relato de um feirante entrevistado podemos verificar essas dinâmicas. Segundo ele,

Assim ó, o chorinho da negociação sempre tem, o descontinho aquele "ah, me dá um descontinho". Conforme o cliente a gente dá(...). Aquele que vem murrinhar, murrinhar, que tá sempre te tentando, aquele de repente uma vez tu dá, mas na próxima tu cobra até os centavinhos. (Entrevista 30, feirante-agricultor, 46 anos, produtor de leite e derivados. Vende na feira há 3 anos) (Cassol, 2018, p. 205).

Os relatos acima demonstram como as dinâmicas de negócio e transação na Feira do Pequeno Produtor condenam o uso da barganha enquanto uma prática tolerável entre os atores. Essas dinâmicas diferem das feiras nordestinas, nas quais barganhar os preços é ato diário, corriqueiro e comum. Porém, na medida em que a Feira do Pequeno Produtor mantém relação direta com a agricultura familiar, seus consumidores não se sentem bem em pedir descontos, pois a valorização dos produtos "coloniais" passa também pela aceitação dos preços cobrados.

Finalmente, tais diferenças em relação à instituição da barganha podem estar ligadas às origens culturais e étnicas de formação dos territórios nos quais os mercados analisados 
encontram-se. Enquanto que as feiras nordestinas aproximam-se culturalmente dos mercados árabes e africanos - descritos tradicionalmente como propensos à barganha (Bohanann, 1955; Bohanann \& Dalton, 1962) -, a Feira de Passo Fundo reproduz em seu interior práticas culturais de origem europeia menos afeitas a essas transações. Do mesmo modo, a menor regulação pública e normativa das feiras nordestinas e o caráter popular de seu consumo também podem ser fatores que estejam contribuindo para uma maior liberdade em pechinchar os preços nesses mercados, o que não ocorre no caso de Passo Fundo ${ }^{16}$.

\section{Considerações finais}

Este estudo buscou problematizar uma das principais questões teóricas e conceituais atrelada às análises dos mercados agroalimentares que se referem à imersão social das transações econômicas. Conforme destacamos na introdução, grande parte dos estudos que têm utilizado a sociologia econômica para interpretar os mercados alimentares contemporâneos tem trabalhado a partir da análise das redes sociais de interação ou da definição dos mercados enquanto campo (Beckert, 2010).

Apesar dos resultados alcançados e das contribuições aportadas, entendemos que tanto a abordagem de redes como a dos campos têm deixado de lado os aspectos culturais que compõem a imersão econômica e que explicam as diferenças entre os mercados alimentares. Nesse sentido, adotamos uma abordagem institucionalista na análise dos mercados para entender seus modos de funcionamento e para explicitar os aspectos culturais que orientam as ações econômicas. Assim, estamos propondo uma análise efetiva dos processos de imersão social e não apenas tomando-os como dados a priori.

Argumentamos que os atores sociais, antes de entrarem em interação e conformarem redes de transação e de negócio (mercados), compartilham valores culturais que são anteriores a essas interações. Os atores compram e comercializam em determinados mercados alimentares porque previamente se identificam com eles e com os valores reproduzidos em seu interior. Esses valores, por seu turno, é que são os responsáveis por imergir a economia e orientar modos de gestão, organização e transação econômica entre os atores e seus mercados.

Assim, procuramos demonstrar o que são as instituições sociais do ponto de vista conceitual ou teórico - tema extremamente caro e complicado no interior da sociologia - e, sobretudo, evidenciar como essas instituições são mobilizadas pelos atores nas suas práticas cotidianas de negócio e transação. Seguimos o argumento de Polanyi et al. (1957) e Polanyi (1980) de que a economia estrutura-se e organiza-se sobre uma diversidade de padrões e tipos de transações que são institucionalizadas de maneira diferente de acordo com o contexto ou a época histórica.

As evidências empíricas que estribam estas conclusões foram obtidas mediante análise das três feiras pesquisadas. Em todas elas, verificamos como suas origens distintas atreladas às características históricas e culturais dos territórios nos quais emergem definem um conjunto específico de instituições responsáveis por orientar o modo como os atores transacionam e negociam seus alimentos.

Nesse sentido, podemos afirmar que a construção social dos mercados está conectada diretamente com a construção e reprodução de instituições sociais que se assentam em valores culturais compartilhados pelos atores locais. Tais instituições ajudam a identificar e compreender as maneiras pelas quais os atores interagem economicamente atribuindo sentidos às suas ações (Weber, 1991), sobre quais dimensões esses mercados se estruturam, por que eles diferem entre si e quais motivações/justificações de consumo são mobilizadas pelos consumidores.

16 Tais hipóteses necessitam ser mais bem investigadas, porém agradecemos aos pareceristas da revista que nos chamaram atenção a elas. 
Nos mercados analisados encontramos quatro instituições sociais principais que explicam a construção e a reprodução hodierna desses espaços. A variedade de mercadorias ofertada, o preço cobrado pelos produtos, as relações assentadas na barganha (ou na falta dela) e a qualidade atribuída aos alimentos definem normas sociais e culturais de conduta e de ação econômica que evidenciam a heterogeneidade das práticas de comercialização e consumo dos atores.

Essas dimensões institucionais são essenciais para a construção de políticas públicas de abastecimento que incentivem a adoção de práticas e processos localizados de abastecimento na sociedade contemporânea. Identificar e investigar essas dimensões ajudam a compreender como os atores estruturam suas práticas de negócio no interior dos mercados em que participam, reconhecendo suas dinâmicas culturais e tradicionais e dinamizando os mercados locais.

\section{Referências}

Albuquerque, A. (2003). Sucessões e coexistências do espaço campinense na sua inserção ao meio técnico-científico-informacional: a feira de Campina Grande na interface desse processo (Dissertação mestrado). Programa de Pós-graduação em Geografia, UFPE.

Allaire, G. (2012). The multidimensional definition of quality. In L. Augustin-Jean, H. Ilbert \& N. Rivano (Eds.), Geographical indications and international agricultural trade: the challenge for Asia (pp. 71-90). Palgrave Macmillan.

Almeida, E. (1978). História de Campina Grande. João Pessoa: Editora Universitária/UEPB.

Andrade, M. C. (1973). A terra e o homem no nordeste (3. ed.). São Paulo: Brasiliense.

Araújo, G. (2011). Continuidade e descontinuidade no contexto da globalização: um estudo de feiras em Portugal e no Brasil (1986-2007)(Tese doutorado). UMINHO/UFBA.

Azevedo, P. F. (2016). Emergência de instituições de mercado: a criação de mercados como política para a agricultura. In F. Marques, M. Conterato \& S. Schneider (Eds.), Construção de mercados e agricultura familiar: desafios para o desenvolvimento rural (pp. 209-227). Porto Alegre: Ed. UFRGS.

Beckert, J. (2010). How do fields change? The interrelations of institutions, networks and cognition in the dynamics of markets. Organization Studies, 31(5), 605-627.

Blay-Palmer, A., Santini, G., Dubbeling, M., Renting, H., Taguchi, M., \& Giordano, T. (2018). Validating the city region food system approach: enacting inclusive, transformational city region food system. Sustainability, 10(5), 1680.

Bohanann, P. (1955). Some principles of exchange and investment among the Tiv. American Anthropologist, 57(1), 60-70.

Bohanann, P., \& Dalton, G. (Eds.). (1962). Markets in Africa. Evanston: Northwestern University African Studies, Northwestern University Press.

Bourdieu, P. (2005). O campo econômico. Política e Sociedade, 4(6), 15-75.

Brasil, N., \& Schneider, S. (2020). Anatomia dos mercados imersos: guia metodológico (Produto resultado de projeto de pesquisa "A dinâmica dos mercados agroalimentares no Rio Grande do Sul: mapeamento e análise socioeconômica"). Porto Alegre. Recuperado em 6 de fevereiro de 2020, de https://www.ufrgs.br/agrifood/index.php/component/content/ article/116-relatorios/231-anatomia-dos-mercados-imersos-guia-metodologico?ltemid=437

Callon, M., Méadel, M., \& Rabeharisoa, V. (2012). The economy of qualities. Economy and Society, 31(2), 194-217. 
Carneiro, M. S. (2019). A sociologia dos agenciamentos mercantis e a contribuição de Michel Callon para o estudo dos mercados. Revista Sociedade e Estado, 34(3), 745-767. http:// dx.doi.org/10.1590/s0102-6992-201934030005

Cassol, A. (2018). Instituições sociais e mercados alimentares tradicionais: barganha, preços, variedade, qualidade e consumo em feiras (Tese de doutorado). UFRGS, Porto Alegre.

Cassol, A., \& Niederle, P. (2019). Mercados, sistemas alimentares sustentáveis e desenvolvimento rural: novas práticas à espera de novas políticas. Nota técnica para consultoria de pesquisa sobre Sistemas Agroalimentares e Desenvolvimento Rural. Centro Brasileiro de Análise e Planejamento (CEBRAP).

Dale, G. (2011). Lineages of embeddedness: on the antecedents and successors of a Polanyi concept. American Journal of Economics and Sociology, 70(2), 306-339.

DiMaggio, P., \& Louch, H. (1998). Socially embedded consumer transaction: for what kinds of purchases do people most often use networks? American Sociological Review, 63(5), 619-637.

Durkheim, E. (2010). Da divisão do trabalho social (4. ed.). São Paulo: Martins Fontes.

Escher, F., \& Schneider, S. (2011). A contribuição de Karl Polanyi para a sociologia do desenvolvimento rural. Sociologias, 13(27), 180-219.

Fligstein, N. (2001). The architecture of markets: an economic sociology of twenty-first-century capitalist societies. Princeton: Princeton University Press.

Fritz Filho, L., \& Miguel, L. (2008). A importância do Estado na evolução da agricultura no Planalto Médio do Rio Grande do Sul. In Anais do $4^{\circ}$ Encontro de Economia Gaúcha. Recuperado em 6 de fevereiro de 2020, de www.pucrs.br/eventos/eeg/trabalhos/agricultura-sessa01-1.doc

Gaiger, L. I., Nyssens, M., \& Wanderley, F. (Eds.). (2019). Social enterprise in Latin America: theory, models and practice (Routledge Studies in Social Enterprise \& Social Innovation). Abingdon: Routledge.

Garcia, M. F. (1984). Feira e trabalhadores rurais: as feiras do Brejo e do Agreste Paraibano (Tese de doutorado). Rio de Janeiro, UFRJ.

Gazolla, M., \& Schneider, S. (Eds.). (2017). Cadeias curtas e redes agroalimentares alternativas: negócios e mercados da agricultura familiar. Porto Alegre: Ed. UFRGS.

Gemici, K. (2008). Karl Polanyi and the antinomies of embeddedness. Socio-economic Review, 6(1), 5-33.

Goodman, D., DuPuis, E., \& Goodman, M. (2012). Alternative food networks. London: Routlege.

Granovetter, M. (2007). Ação econômica e estrutura social: o problema da imersão. RAE Eletrônica, 6(1), 9. http://dx.doi.org/10.1590/S1676-56482007000100006.

Grivins, M., \& Tisenkopfs, T. (2018). Benefitting from the global, protecting the local: The nested markets of wild product trade. Journal of Rural Studies, 61, 335-342. http://dx.doi. org/10.1016/j.jrurstud.2018.01.005.

Hebink, P., Ploeg, J. D., \& Schneider, S. (Eds.). (2014). Rural development and the construction of new markets. Haia: Routledge.

Krippner, G. (2001). The elusive market: embeddedness and the paradigm of economic sociology. Theory and Society, 30(6), 775-810. http://dx.doi.org/10.1023/A:1013330324198

Machado, N. (2010). Karl Polanyi e a nova sociologia económica: notas sobre o conceito de (dis) embeddedness. Revista Critica de Ciencias Sociais, 90(90), 71-94. http://dx.doi.org/10.4000/ rccs. 1771 
Maluf, R. S., \& Luz, L. F. (2018). Sistemas alimentares descentralizados: um enfoque de abastecimento na perspectiva da soberania e segurança alimentar e nutricional. In R. S. Maluf \& G. Flexor (Eds.), Questões agrárias, agrícolas e rurais: conjunturas e políticas públicas (1. ed., pp. 214-224). Rio de Janeiro: E-Papers.

Maucourant, J., \& Plociniczak, S. (2013). The institution, the economy and the Market: Karl Polanyi's institutional thought for economists. Review of Political Economy, 25(3), 512-531. http://dx.doi.org/10.1080/09538259.2013.807675

Miranda, F., \& Machado, I. (2005). Passo Fundo: presentes da memória. Rio de Janeiro: MM Comunicação.

Mott, L. (1975). A feira de Brejo Grande: um estudo de uma instituição econômica num município sergipano do baixo São Francisco (Tese de doutorado). UNICAMP, Campinas.

Niederle, P., \& Wesz Junior, V. (2018). As novas ordens alimentares. Porto Alegre: Ed. UFRGS.

Palmeira, M. (2014). Feira e mudança econômica. Virtual Brazilian Anthropology, 11(1), 324-360.

Ploeg, J. D. (2016). Mercados aninhados recém-criados: uma introdução teórica. In F. C. Marques, M. Conterato \& S. Schneider (Eds.), Construção de mercados e agricultura familiar: desafios para o desenvolvimento rural (pp. 21-51). Porto Alegre: Ed. UFRGS.

Polanyi, K. (1976). La economía como actividad institucionalizada. In K. Polanyi, C. Arensberg \& H. Pearson (Eds.), Comercio y mercado en los imperios antiguos (pp. 289-316). Barcelona: Labor Universitária.

Polanyi, K. (1980). A grande transformação: as origens de nossa época. Rio Janeiro: Campus.

Polanyi, K., Arensberg, C., \& Pearson, H. (1957). Trade and market in the early empires. Illinois: The Falcon's Wing Press.

Raud, C. (2005). A construção social do mercado em Durkheim e Weber: análise do papel das instituições na sociologia econômica clássica. Revista Brasileira de Ciências Sociais, 20(57), 127-142.

Sabourin, E. (2011). Teoria da reciprocidade e sócio-antropologia do desenvolvimento. Sociologias, 13(27), 24-51.

Schneider, S. (1999). Agricultura familiar e industrialização: pluriatividade e descentralização industrial no Rio Grande do Sul. Porto Alegre: Ed. UFRGS.

Schneider, S., \& Cassol, A. (2020). Food and markets: the contribution of economic sociology. In J. Duncan, M. Carolan \& M. Wiskerke (Eds.), The Routledge handbook of sustainable and regenerative food systems (pp. 171-187). England: Routledge.

Weber, M. (1991). Economia e sociedade: fundamentos da sociologia compreensiva. Brasília: Ed. Unb.

White, H. (1981). Where do markets come from? American Journal of Sociology, 87(3), 517-547.

Wong, F. (2020). The emerging worldview: how new progressivism is moving beyond neoliberalism: a landscape analysis. Roosevelt Institute. Recuperado em 6 de fevereiro de 2020, de https:// rooseveltinstitute.org/wpcontent/uploads/2020/01/RI_EmergingWorldview_report-202001-1. pdf 